\title{
Biosorption technology for removal of metallic pollutants-An overview
}

\section{A.K. Chopra and Chakresh Pathak*}

Department of Zoology and Environmental Science, Gurukula Kangri University, Haridwar-249404 (Uttarakhand), INDIA

*Corresponding author. E-mail: chakreshpathak@yahoo.co.in

Abstract: The main sources of metallic pollutants to the environment are the diffuse sources such as forests and agricultural soils as well as industrial and municipal wastes, which are either discharged directly or transported in to the environment. Various conventional technologies such as chemical precipitation, solvent extraction, ion exchange, membrane separation, electrochemical treatment etc. have been employed to remove metal pollutants from aqueous solution. The exploration of new technologies involves the removal of toxic metals from wastewater with the use of biological adsorption technology. The biosorption is the selective appropriate process for removal of metal ions uptake that may involve the contribution of diffusion, adsorption, chelation, complexation, coordination, or micro-precipitation mechanisms, depending on the specific substrate (biomass). In this overview, the use of the various low cost, easily available and eco-friendly biosorbents used for removal of metallic pollutants from contaminated water and their mechanism are discussed.

Keywords: Biosorption, Metallic pollutants, Algae, Fungi, Bacteria and Agricultural by-product.

\section{INTRODUCTION}

Heavy metal pollution in the aquatic system has become a serious threat and it is of great environmental concern as these metals are non-biodegradable. Nowadays, the increasing use of the waste chemical and agricultural drainage systems represent the most hazardous chemical pollution. The most important heavy metals from the point of view of water pollution are $\mathrm{Zn}, \mathrm{Cu}, \mathrm{Pb}, \mathrm{Cd}, \mathrm{Hg}, \mathrm{Ni}$ and $\mathrm{Cr}$ (Table 1). Some of these metals $(\mathrm{Cu}, \mathrm{Ni}, \mathrm{Cr}$ and $\mathrm{Zn}$ ) are essential trace metals to living organisms, but become toxic at higher concentrations. Metals are mobilized and carried into food web as a result of leaching from waste dumps, polluted soil and water.

Heavy metals are groups of pollutants, which are not biodegradable and tend to accumulate in living organisms (Kobya et al., 2005). Release of large quantities of heavy metals into the natural environment has resulted in a number of environmental problems (Hanif et al., 2007). Their removal and recovery of heavy metals from wastewater are more important to protect public health and environment (Francesca et al. 2003; Guangyu and Thiruvenkatachari, 2003; Cesar and Marco, 2004 and Chen et al., 2008). Conventional methods such as precipitation, oxidation/reduction, ion exchange, filtration, membranes and evaporation which are in use are extremely expensive or inefficient for metal removal from diluted solutions containing from 1 to $100 \mathrm{mg} / \mathrm{L}$ of dissolved metal. In this context, the biosorption process has been evaluated (Volesky, 1990). The biosorption is the ability of biological materials to accumulate heavy metals from wastewater through metabolically mediated or physicochemical pathways of uptake. (Fourest et al., 1992). Volesky and Schiewer (1999) have studied the uptake of contaminants via various physico-chemical mechanisms by inactive/ dead biological materials that are relatively easy to operate and possess several inherent advantages, including low cost, operation over a wide range of conditions and possible reuse of biosorbents. Yun et al. (2001) and Yun (2004) have observed that for certain biosorbents in biosorption numerous groups, carboxyl, carbonyl, sulfonate, sulfhydryl, phosphonate, and hydroxyl groups contribute to binding contaminants.

Among the various resources in biological wastes, both dead and live biomass, exhibit particularly interesting metal-binding capacities. Many workers have used different biosorbents, including China clay (Gupta et al., 1992), bentonite, steel-plant slag, fly ash (Ramakrishna and Viraraghavan, 1997), waste slurry (Yun, 2004), bagasse pith, maize cobs, sunflower, peat, orange peel, saw dust, corynebacterium glutamicum (Won et al., 2005 and Crini, 2006), and rice husk (Kumar and Bandyopadhyay, 2006) for the removal of contaminants from wastewater. In recent years, agricultural by-products have been widely used for metal removal from wastewater. These include peat, wood, pine bark, banana pith, soybean, and cottonseed hulls, peanut, shells, hazelnut shell, rice husk, sawdust, wool, orange peel, compost, humic substances, and leaves. The use of dead biomass eliminates the 
problem of toxicity and the economics aspects of nutrient supply and culture maintenance.

The advantages of biosorption lie in both the good performance in metal removal, often comparable with their commercial competitors (ion exchangers), and costeffectiveness, making use of raw materials for fermentation and the agricultural processes. This aspect can play an important role in improving a zero-wastes economic policy especially in case of the re-use of biomasses coming from food, pharmaceuticals, and wastewater treatments. The major advantages of biosorption over conventional treatment methods include low cost, high efficiency of metal removal from dilute solution, minimization of chemical and /or biological sludge, no additional nutrient requirement, regeneration or biosorbent and the possibility of metal recovery (Kratochvil and Volesky, 1998; Radway et al., 2001, Omar, 2002 and 2008).

\section{METALLIC POLLUTION IN ENVIRONMENT AND ITS EFFECTS}

Contamination of heavy metals in the environment is of major concern because of their toxicity and threat to human life and the environment. The main sources of heavy metals to the environment are diffuse sources such as forest and agricultural soils as well as industrial and municipal waste, which are either discharged directly or transported in to the environment. Inputs from diffuse sources are mainly the result of old environmental sinks that after decades continue to leach pollutants into waterways via runoff. Hazardous substances from industries are emitted from all stages of the product chain - from the raw material and the production and combustion processes, from the use of products and from the handling of products as waste.

Water pollution due to heavy metals is an issue of great environmental concern Several small and heavy industries are involved in the activities such as battery and paint manufacturing, petroleum refining, cement and ceramic production, steel production which contribute to the release of significant amounts of metals among other toxic substances into the marine environment and directly affect surface water and quality of sediments. Heavy metals have been used in many different areas for thousands of years. Heavy metal ions such as cobalt, copper, nickel, chromium, lead and zinc are detected in the waste streams from mining operations, tanneries, electronics, electroplating, batteries and petrochemical industries as well as textile mill products. Major lead pollution is through automobiles and battery manufacturers (Adesola Babarinde et al., 2006). The chemically polluted water has seriously damaged the ecology of surface and ground water, which eventually impart serious consequences on agriculture due to contamination of crops grown in a polluted area (Mufti et al., 1997). Penalties for the discharge of untreated waste water pose large financial pressures on industrialists and treatment of waste water containing heavy metals is becoming most popular and financially sustainable (Jooste, 2000).Many heavy metals and their compounds have been found toxic, while some are also subjected to biomagnifications (Karvelas et al., 2003).

The main source of pollution in sewage is human excreta, with smaller contribution from food preparation washing laundry, surface drainage etc. Domestic wastewater is composed mainly of proteins (40-60 percent), carbohydrates to a range of $25-50$ per cent, fats and oils (1.0 per cent), urea derived from urine and a large number of trace organics, which include pesticides, surfactants, phenols, and priority pollutants. The latter category comprises nonmetals (As, $\mathrm{Se})$, metals $(\mathrm{Cd}, \mathrm{Hg}, \mathrm{Pb})$ and aromatic compounds like, benzene, ethyl benzene, lindane, tetrachloroether, trichloroether (Metchalf and Eddy, 1991). The hexavalent and trivalent chromium is often present in electroplating wastewater (Kratochvil et al., 1998). Other sources of chromium pollution are leather tanning, textile, metal processing, paint and pigments, dyeing and steel fabrication. Lead is used as industrial raw material in the manufacture of storage batteries, pigments, leaded glass, fuels, photographic materials, matches and explosives (Raji and Anirudhan, 1997). The main source of pollution in sewage is human excreta, with smaller contribution from food preparation washing laundry, surface drainage etc (Preetha and Kumar, 2008). Industrial wastewater is heavily loaded with different types of inorganic and organic pollutants, which are discharged through aquatic routes either in water soluble or insoluble forms. In this regard, occurrence of heavy metals in the aquatic system has become a global phenomenon due to their carcinogenic and mutagenic nature (Javaid and Bajwa, 2008). The sad thing about the pollution of the environment with heavy metals is that they can not be biologically degraded, they can only be transformed from one oxidation state or organic complex to another (Jing et al., 2007 and Lone et al., 2008).

Heavy metals have a harmful effect on human physiology and other biological systems when they exceed the tolerance levels (Kobya et al., 2005). Exposure to lead can cause anaemia, diseases of the liver and kidneys, brain damage and ultimately death (Jain et al., 1989). Besides, chronic exposure to these contaminants present even at low concentrations in the environment can prove to be harmful to the human health. For these reasons, heavy metals must be removed as much as possible from industrial effluents.

Acute lead poisoning in humans may cause severe damage of kidneys, liver, brain and control nervous system leading to sickness or death. The effect of 
cadmium poisoning on human are very serious. They include high blood pressure, kidney damage, and destruction of red blood cells (Mustafa and Idris, 2003). The toxicity of metals most commonly involves the brain and the kidney, but other manifestations occur, and some metals, such as arsenic, are clearly capable of causing cancer. An individual with metals toxicity, even if high dose and acute, typically has very general symptoms, such as weakness or headache. This makes the diagnosis of metals toxicity in a clinical setting very difficult unless a clinician has the knowledge and training to suspect the diagnosis and is able to order the correct diagnostic test. Chronic exposure to metals at a high enough level to cause chronic toxicity effects (such as hypertension in individuals exposed to lead and renal toxicity in individuals exposed to cadmium) can also occur in individuals who have no symptoms. Agency for toxic substances and disease registry (ATSDR) (1999a) have reported ninety-nine percent of the lead that enters the adult human body and 33\% that enters a child's body is excreted in about 2 weeks. Because of this, lead poisoning is a greater concern in children. Mobilized lead can be redeposited in the soft tissues of the body and can cause musculoskeletal, renal, ocular, immunological, neurological, reproductive, and developmental effects (Todd et al., 1996; and ATSDR, 1999a). Various reproductive effects including decreased pregnancy rate, ovarian damage, testicular damage, testicular atrophy, cellular degeneration, and irregular estrous cycles have been shown in animal studies (ATSDR, 1999a). Copper is an essential substance to human life, but in high doses it can cause anemia, liver and kidney damage, and stomach and intestinal irritation.

Zinc deficiency in the diet may be more detrimental to human health than too much zinc in the diet (ATSDR, 1994). Although the average daily intake of zinc in the United States is 7-16.3 $\mathrm{mg} \mathrm{Zn/day,} \mathrm{the} \mathrm{Recommended}$ Daily Allowance (RDA) for zinc is $15 \mathrm{mg} \mathrm{Zn} /$ day for man and $12 \mathrm{mg} \mathrm{Zn/day} \mathrm{for} \mathrm{women} \mathrm{(ATSDR,} \mathrm{1994).} \mathrm{Vomiting,}$ diarrhea, abdominal cramping, and, in some cases, intestinal hemorrhage can occur from long-term exposure to high (i.e. $>85 \mathrm{mg} / \mathrm{kg} /$ day) doses of zinc. Zinc is not a human carcinogen.

Cadmium is often a byproduct of the extraction of $\mathrm{Pb}$, $\mathrm{Zn}$, and $\mathrm{Cu}$ from their respective ores (ATSDR, 1999b). Carbonaceous shale, coal, and other fossil fuels are also a source of $\mathrm{Cd}$. Anthropogenic sources of $\mathrm{Cd}$ in the soil and groundwater include the use of commercially available fertilizers and the disposal of sewage sludges as soil amendments (Baker et al., 1979, Garcia et al., 1979, Kosla, 1986, Peles et al., 1998, Gallardo-Lara etal., 1999). EPA has established RfDs for Cd of $0.001 \mathrm{mg} \mathrm{Cd} / \mathrm{kg} /$ day for food and $0.0005 \mathrm{mg} \mathrm{Cd} / \mathrm{kg} /$ day for water. These amounts represent an estimated daily oral exposure that is likely not to cause adverse health effects (EPA, 1994).

\section{BIOSORBENTS USED FOR WASTE WATER}

\section{TREATMENT}

Biosorption of heavy metals by microbial cells has been recognized as a potential alternative to existing technologies for waste streams and natural waters. Biosorbents for the removal of metals mainly come under the following categories: algae, bacteria, fungi, industrial wastes, agricultural wastes and other polysaccharide materials (Table 2). Microorganisms are known to accumulate metals by two distinct processes; (i) bioaccumulation, an energy-dependent process, and (ii) biosorption, an energy independent physical adsorption (Akthar et al., 1995). In general, all types of biomaterials have shown good biosorption capacities towards all types of metal ions.

Algae: The algae have many features that make them ideal for the selective removal and concentration of heavy metals, which include high tolerance to heavy metals, ability to grow both autotrophically and heterotrophically, large surface area/volume ratios, phototaxy, phytochelatin expression and potential for genetic manipulation (Suresh and Ravishankar, 2004). Algae possess high metal binding capacities, due to the presence of polysaccharides, proteins or lipid on the cell wall surface containing functional groups such as amino, hydroxyl, carboxyl, and sulphate, which could act as binding sites for metals (Sheng et al., 2004; Patricia et al., 2006; Vitor et al., 2007; Deng et al., 2007; Olga et al., 2008). The use of algae in bisorption is low as compared to those using other biomass (mainly fungi and bacteria), and the number is still lower for multimetallic systems (Romera et al., 2006). Many studies have shown that the factors influencing biosorption by non-viable algae include heavy metal species (Fourest and Volesky, 1997), pH (Yu and Kaewsarn, 1999), competing ions (Lau et al., 1999) and the types of algae (Radway et al., 2001). Omar (2008) carried out a study on biosorption of copper, nickel and manganese using non-living biomass of marine alga, Ulva lactuca. The results of this study indicated that the biomass of UIva lactuca is suitable for the development of an efficient metal removal system for the removal of $\mathrm{Cu}^{2+}, \mathrm{Ni}^{2+}$ and $\mathrm{Mn}^{2+}$ from the aqueous solution. Biosorption of these metals on the algal biomass showed a higher affinity for $\mathrm{Cu}^{2+}$ compared to $\mathrm{Ni}^{2+}$ and $\mathrm{Mn}^{2+}$. Alfawwaz and Wan Maznah (2008) studied that biosorption of copper using live and dead green microalgae isolated from Penang rivers, Malaysia. The copper biosorptive capacity of green microalgae (Chlorella sp., and Scenedesmus sp.) has been studied to find the differences in copper uptake using live and dead microalgae in aqueous solutions. The study indicated that using dead Chlorella and Scenedesmus sp. was better than using 
Table 1. Water quality standards by the Indian standards for drinking IS 100500-1991, World Health Organization (WHO) and National Agency for Food and Drugs Administration and Control (NAFDAC), Nigeria (Source: Duruibe et al., 2007).

\begin{tabular}{lccc}
\hline M etals & $\begin{array}{c}\text { Indian standards for } \\
\text { water quality }\end{array}$ & $\begin{array}{c}\text { Max. acceptable } \\
\text { conc. (WHO) }\end{array}$ & $\begin{array}{c}\text { Max. acceptable } \\
\text { conc. (NAFDAC) }\end{array}$ \\
\hline Zinc & 1.5 & $5 \mathrm{mg} / \mathrm{l}$ & $5 \mathrm{mg} / \mathrm{l}$ \\
Arsenic & 0.05 & $0.01 \mathrm{mg} / \mathrm{l}$ & $0.0 \mathrm{mg} / \mathrm{l}$, \\
Magnesium & - & $50 \mathrm{mg} / 1$ & $30 \mathrm{mg} / 1$ \\
Calcium & - & $50 \mathrm{mg} / 1$ & $50 \mathrm{mg} / 1$ \\
Cadmium & - & $0.003 \mathrm{mg} / 1$ & $0.0 \mathrm{mg} / \mathrm{l}$ \\
Lead & 0.1 & $0.01 \mathrm{mg} / 1$ & $0.0 \mathrm{mg} / 1$ \\
Mercury & - & $0.001 \mathrm{mg} / \mathrm{l}$ & $0.0 \mathrm{mg} / \mathrm{l}$ \\
Silver & - & $0.0 \mathrm{mg} / 1$ & $0.0 \mathrm{mg} / \mathrm{l}$ \\
\hline
\end{tabular}

live one and the biosorption efficiency for Chlorella sp. was better than Scenedesmus sp.

Antunes et al. (2003) investigated the removal of copper ions from aqueous solutions by Sargassum sp. that was conducted in batch conditions and found that the copper uptake capacity $(1.48 \mathrm{mmol} / \mathrm{g}$ biomass $)$ of Sargassum sp. proved to be an excellent biomaterial for accumulating and recovering copper from industrial solutions. Ayla et al. (2004) carried out a study on the equilibrium and kinetic modelling of the Biosorption of copper (II) ions on Cladophora crispate and concluded that the $\mathrm{pH}$, the initial metal ion concentration and temperature affected the equilibrium uptake of $\mathrm{Cu}$ (II) ions to $\mathrm{C}$. crispata and the optimum initial $\mathrm{pH}$, the initial copper (II) ion concentration and temperature were determined as 4.5 , $200 \mathrm{mg} \mathrm{L}^{-1}$ and $25^{\circ} \mathrm{C}$, respectively. The maximum biosorption capacity of algal biomass was determined as $1.03 \mathrm{mmol} \mathrm{g"1}$. A comparison of sorption capacity of C. crispata with those obtained in the literature for the adsorption of $\mathrm{Cu}$ (II) ions on some other biosorbents and adsorbents also showed that $\mathrm{C}$. crispata was more effective for this purpose. Vieira et al. (2007) carried out a study on biosorption of lead by the brown seaweed Sargassum filipendula - batch and continuous pilot studies and results that were obtained in a continuous system showed a gradual saturation of the biomass in the reactors.

Bacteria: The metal removal ability of microorganisms including bacteria (Lo et al., 1999) has been studied extensively. Microorganisms can affect heavy metal concentrations in the environment because they exhibit a strong ability for metal removal from solution through enzymatic or nonenzymatic mechanisms (Rajendran et al., 2002). According to Beveridge (1989), bacteria make excellent biosorbents because of their high surface-tovolume ratios and a high content of potentially active chemosorption sites such as on teichoic acid in their cell walls. Churchill et al. (1995) used two Gram-negative strains Escherichia coli K-12 and Pseudomonas aeruginosa and a Gram-positive strain Micrococcus luteus to demonstrate biosorption of $\mathrm{Cu}^{2+}, \mathrm{Cr}^{3+}, \mathrm{Co}^{2+}$ and $\mathrm{Ni}^{2+}$. Their sorption binding constants suggested that $\mathrm{E}$. coli cells were the most efficient at binding copper, chromium and nickel and $M$. luteus sorbed cobalt most efficiently. The heavy metal removal capacity is higher than those conventional methods and the uptake of heavy metals can be selective (Unz and Shuttleworth, 1996). Microbial cells can also be supplied inexpensively as waste in industrial fermentation processes as well as biological wastewater treatment plants (Volesky and MayPhillips, 1995). Hu etal. (1996) worked with Pseudomonas aeruginosa strain CSU, a genetically not altered bacterial strain known to bind dissolved hexavalent uranium. P. aeruginosa CSU biomass was sorbing significantly more uranium than certain novel, patented biosorbents derived from algal or fungal biomass sources. A good basis for ongoing work in the field of bacterial metal biosorption has been provided by Mann (1990), which remains very attractive and exciting for the study. Most of the experiments done with metals and bacteria have really concerned metabolically mediated bioaccumulation, while the basic principle of biosorption is the use of dead biomass. Leung et al. (2000) studied on removal and recovery of heavy metals by bacteria isolated from activated sludge treating industrial effluents and municipal wastewater. Pseudomonas pseudoalcaligenes and Micrococcus luteus were found to be capable of removing significant amounts of copper and lead. Kaewchai and Prasertsan (2002) made a study on biosorption of heavy metal by thermotolerant polymerproducing bacterial cells and the bioflocculant. Three strains of thermotolerant polymer-producing bacteria; Bacillus subtilis WD 90, Bacillus subtilis SM 29 , and Enterobacter agglomerans SM 38 as well as their biofloculants were used to investigate on the adsorption of heavy metal, nickel and cadmium. Adsorption of nickel and cadmium by the bioflocculant from the three selected strains was higher than that by the cells. 
Fungi: Fungal biomass offers the advantage of having a high concentration of cell-wall material that shows excellent binding (Rajendran et al., 2002). Tomko et al. (2006) studied on biosorption of heavy metals by dry fungi biomass. Fungal biosorbents can sorbs heavy metals such as $\mathrm{Cu}, \mathrm{Al}$ and $\mathrm{Sb}$ from aqueous solution and the process is dependent on fungal species, biosorbent size and concentration, solution $\mathrm{pH}$ and ionic composition. Differences in biosorption ability found between fungi species tested are interesting. Agaricus campester rich the highest heavy metals sorption efficiency, except of $\mathrm{Cu}$. The highest metal uptake (at about $95 \%$ ) was observed in the case of $\mathrm{Sb}$, except of fungus Amanita muscaria. In addition, biosorption by both active and inactivated microorganisms is an important process in the biogeochemical cycling of metals, radionuclides and anthropogenic organics, and should be fully studied in order to understand the source and fates of these chemicals. Wuyep et al. (2007) made a study on biosorption of $\mathrm{Cr}, \mathrm{Mn}, \mathrm{Fe}, \mathrm{Ni}, \mathrm{Cu}$ and $\mathrm{Pb}$ metals from petroleum refinery effluent by calcium alginate immobilized mycelia of P olyporus squamosus. $\mathrm{pH}$ played an important role in the biosorption capability of the immobilized P. squamosus, with the fungal biomass having maximum adsorption for cationic metal ions at $\mathrm{pH} 4-6$. The results of this investigation could provide a basis for applying the white rot fungi for an environmentally friendly and economically feasible decontamination of pollutants and concluded that $P$. squamosus, a white rot fungus has biosorption capability, by being able to sequester subtantial amounts of heavy metals from effluents. Previously, the ability of white rot fungi to degrade recalcitrant pollutants has been demonstrated. This ability is probably largely due their elaborate ligninolytic enzymes. It is difficult to say whether these heavy metals were biodegraded.

Liu et al. (2007) made a study on removal of hexavalent chromium by fungal biomass of Mucor racemosus: influencing factors and removal mechanism. The optimum $\mathrm{pH}$, biomass dose, initial $\mathrm{Cr}(\mathrm{VI})$ concentration and contact time were investigated thoroughly to optimize the removal condition. The metal removal by the biomass was strongly affected by $\mathrm{pH}$ and the optimum $\mathrm{pH}$ ranged from 0.5 to 1.0. At biomass dose $6 \mathrm{~g} / 1$, almost all the $\mathrm{Cr}(\mathrm{VI})$ ions were removed in the optimum condition. Higher removal percentage was observed at lower initial concentrations of $\mathrm{Cr}$ (VI) ions, while the removal capacity of the biomass linearly depended on the initial $\mathrm{Cr}$ (VI) concentration. More than half of $\mathrm{Cr}(\mathrm{VI})$ ions were diminished within $1 \mathrm{~h}$ of contact and removal process reached a relative equilibrium in approximately $8 \mathrm{~h}$. almost all of the $\mathrm{Cr}(\mathrm{VI})$ ions were removed in $24 \mathrm{~h}$ when initial concentrations were below $100 \mathrm{mg} / \mathrm{l}$.

Subbaiah et al. (2008) studied on biosorption of Cr (VI) from aqueous solutions using Trametes Versicolor Polyporus Fungi. The results of the present study demonstrated that $T$. versicolor polyporous fungi were excellent biosorbent for the removal of chromium ions. The maximum uptake of $\mathrm{Cr}(\mathrm{VI})$ ions occurred at $\mathrm{pH} 4$. Increase in the amount of biosorbent increased the percent removal of the metal ions.

Agricultural by-products: Removal of heavy metals from industrial wastewater is of primary importance. Disposal of agricultural by-products such as cassava wastes from processing activities is becoming a concern in Nigeria due to its foul dour. Contamination of water by heavy metals is another serious ongoing problem because of indiscriminate discharges of wastewater containing heavy metals by small and medium-scale industries. Horsfall et al. (2003) made a study on removal of $\mathrm{Cu}$ (II) and $\mathrm{Zn}$ (II) ions from wastewater by cassava (M anihot esculenta Cranz) waste biomass.

A number of investigations have been conducted to test the low cost adsorbents for heavy metal ion removal over the last few years. Such alternatives include agricultural biowastes (Park et al., 2008). Pino et al. (2006) studied on biosorption of heavy metals by powder of green coconut shell. Several investigations have been carried out to identify suitable and relatively cheap biosorbents that are capable of removing significant quantities of ions. Among the various resources in biological wastes, both dead and live biomass, exhibit particularly interesting metal-binding capacities. In recent years, agricultural byproducts have been widely studied for metal removal from water. These include peat, wood, pine bark, banana pith, soybean, and cottonseed hulls, peanut, shells, hazelnut shell, rice husk, sawdust, wool, orange peel, compost, humic substances, and leaves (Chandra et al., 2003 and Tipping, 2002). Olayinka et al. (2007) studied on sorption of heavy metals from electroplating effluents by low-cost adsorbents II like use of waste tea, coconut shell and coconut husk and concluded that the use of coconut husk, coconut shell and waste appears to be technically feasible, eco friendly with high efficiency in the removal of heavy metals from wastewaters. Besides, it is composed entirely of agricultural waste and this helps in the reduction of waste generation. They adsorbed comparatively like the expensive traditional activated carbon.

The diffusion of the metals from the bulk solution to active sites of biosorbents predominantly occurs by passive transport mechanisms and various functional groups such as carboxyl, hydroxyl, amino and phosphate existing on the cell wall of biosorbents which can bind the heavy metals. Tree leaves from agricultural operations have generally little or no economic value (Veglio and Beolchini, 1997 and Volesky, 2001). Cost is an important parameter for comparing the sorbent materials (Bailey et 

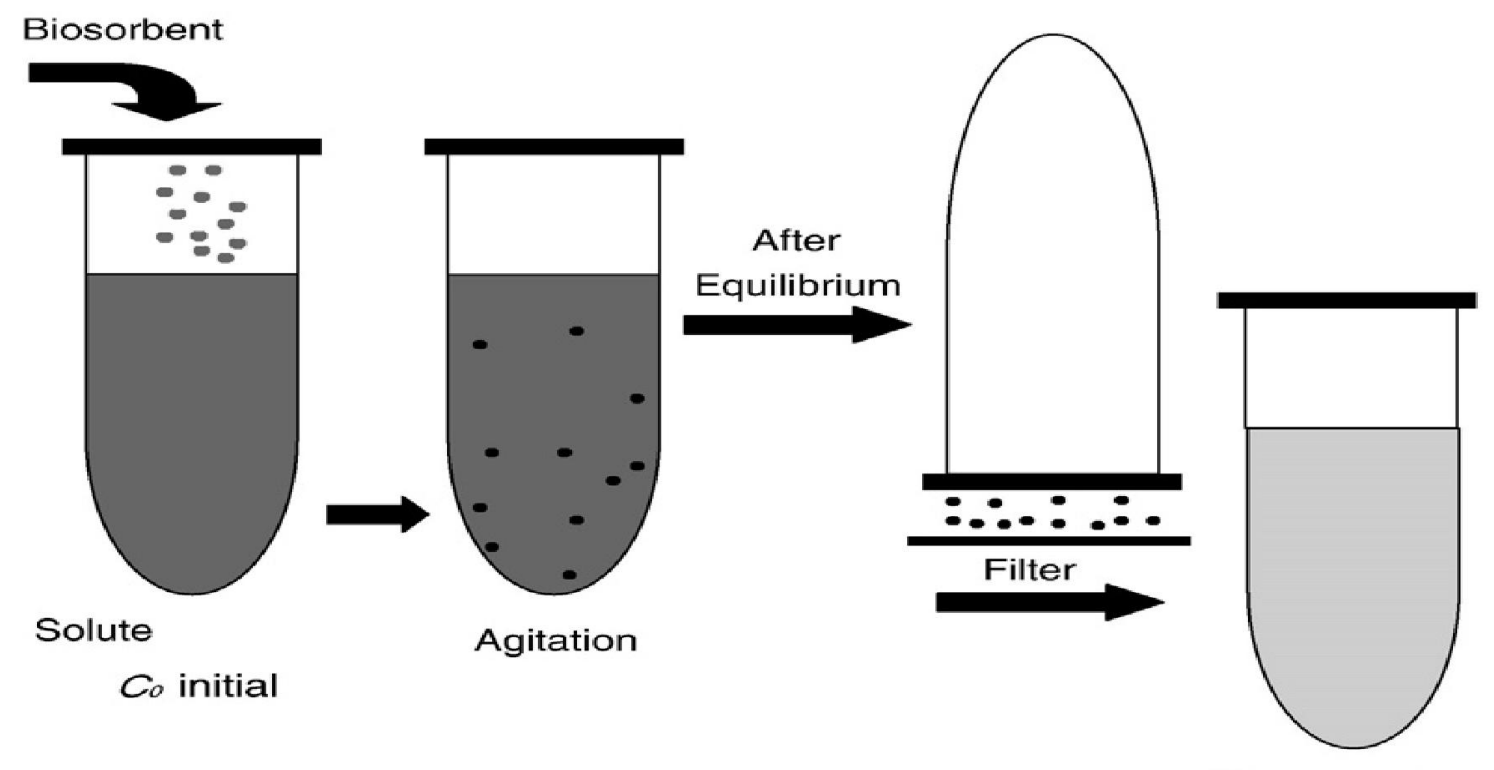

Filtrate analyzed

$C_{f}$ final

Fig. 1. Schematic diagram of batch biosorption equilibrium experimental procedure (Source: Vijayaraghavan and Yeoung- Sang, 2008).

\section{al., 1999).}

Adsorption has emerged as a cost-effective and efficient alternative for removing heavy metals from low strength wastewaters (Manju and Anirudhan, 1997, Raji and Anirudhan, 1997, Warhusta et al., 1997). Rice husk are an agricultural waste produced in excess of 100 million tons as a by-product of the rice milling industry of which $96 \%$ is generated in developing countries. The utilization of this source of biomass would solve some disposal problem as well as access to cheaper materials for adsorption in water pollutants control system (Williams and Nugranad, 2000).

\section{BIOSORPTION MECHANISM}

The mechanism of metal biosorption is a complicated process. It is rather a complex process affected by several factors viz. the status of biomass (living or non living), types of biomaterials, properties of metal solution chemistry, ambient/environmental conditions such as $\mathrm{pH}$, influence the mechanism of metal biosorption (Fig. 1.). Most investigations demonstrated that biosorption mechanism for metals is very complicated, and involved in many processes, such as oxidation-reduction (Hosea et al., 1986 and Schiewer, 1999), ion exchange (Kuyucak and Volesky, 1989 and Kapoor and Viraraghavan, 1997), surface complexation (Guibal et al., 1995 and Figueira et al., 1999), co-precipitation (Strandberg et al ., 1981; Tsezos and Volesky, 1982, Churchill et al., 1995; Wase and Forster; 1997, Brown et al., 2000, Schneider, 2001; Volesky ;2001 and Pino et al., 2006) adsorption induced by static electricity or enzyme (Ashkenazy et al., 1997) etc.. Additionally, many techniques have been used for the investigation in biosorption mechanism of metals (Sarret et al., 1999 and Gardea-Torrsday et al., 2004), such as infra-red spectrum (IR), nuclear magnetic resonance (NMR), transmission electron microscope (TEM), electron energy loss spectrometer (EELS), electron dispersive spectroscopy (EDS), X-ray photoelectron spectroscopy (XPS), extended X-ray absorption fine structure (EXAFS), time-resolved laser induced fluorescence spectroscopy (TRLFS), even particle induced X-ray emission (PIXE) analysis (Liao et al., 2008). The metal biosorption mechanism by living cells is a two step process. In the first step, metal ions are adsorbed to the surface of cells by interactions between metals and functional group displayed on the surface of cells. All the metal ions before gaining access the cell wall. The cell wall consists of a variety of polysaccharide and protins and hence offers a number of active sites capable of binding metal ions. Difference in the cell wall composition among the different group of microorganism, viz. algae bactria, cynobacteria and fungi cause significant difference in the type amount of metal ion binding to them. Algal cell walls are mainly cellulosic. The potential metal binding groups in this class of microbes are carboxylates, amines, imizadoles are positively charged when protonated and may build negatively charged metal complexes. The first step, passive biosorption, is metabolism independent and proceeds rapidly by any one or a combination of the following metal binding mechanism coordination, complexation, ion exchange or inorganic microprecipitation. In the second step, due to active biosorption, metal ions penetrate the cell membrane and enter into the cells. Actually, there are many modes of non-active metal uptake by (microbial) biomass. Any 
Table 2. Summary of metal removal by different biosorbents.

\begin{tabular}{|c|c|c|c|c|}
\hline \multirow[t]{2}{*}{ M etals } & \multicolumn{3}{|c|}{ Biosorbents } & \multirow[t]{2}{*}{ References } \\
\hline & Algae & Bacteria, $\mathrm{F}$ ungi and $\mathrm{Y}$ east & Agricultural product & \\
\hline $\mathrm{Cu}$ & $\begin{array}{l}\text { Chlorella sp., } \\
\text { Scenedesmus sp. }\end{array}$ & $\begin{array}{l}\text { Pseudomonas putida, } \\
\text { Streptomyces, coelicolor, } \\
\text { Sphaerotilus natans }\end{array}$ & - & $\begin{array}{l}\text { Al-fawwaz and } \\
\text { Wan Maznah (2008), } \\
\text { Uslu and Tanyol, 2006, } \\
\text { Öztürk et al., 2004, } \\
\text { Beolchini et al., 2006 }\end{array}$ \\
\hline $\mathrm{Hg}$ & Spirogyra species & Bacillus sp. & - & $\begin{array}{l}\text { Rezaee et al., 2006, } \\
\text { Green-Ruiz, } 2006\end{array}$ \\
\hline $\mathrm{Cd}$ & - & $\begin{array}{l}\text { Aeromonas caviae, Bacillus } \\
\text { circulans } \\
\text { and Pseudomonas sp. }\end{array}$ & Green Coconut Shell & $\begin{array}{l}\text { Loukidou et al., 2004, } \\
\text { Yilmaz and Ensari, 2005, } \\
\text { Pino et al., 2006, } \\
\text { Ziagova et al., } 2007\end{array}$ \\
\hline $\mathrm{Pb}$ & Chlorella vulgaris & $\begin{array}{l}\text { Pseudomonas putida, } \\
\text { Corynebacterium glutamicum }\end{array}$ & - & $\begin{array}{l}\text { Hameed, 2006, } \\
\text { Uslu and Tanyol, 2006, } \\
\text { Choi and Yun, } 2004\end{array}$ \\
\hline $\mathrm{Ni}$ & Ulva Iactuca & $\begin{array}{l}\text { Bacillus thuringiensis, } \\
\text { Streptomyces rimosusa }\end{array}$ & $\begin{array}{l}\text { Waste tea, Coconut Shell } \\
\text { and coconut Husk }\end{array}$ & $\begin{array}{l}\text { Omar, 2008, } \\
\text { Öztürk, 2007, } \\
\text { Selatnia et al., 2004, } \\
\text { Olayinka et al., } 2007\end{array}$ \\
\hline $\mathrm{Zn}$ & Caulerpa lentillifera & Aphanothece hal ophytica & - & $\begin{array}{l}\text { Incharoensakdi and } \\
\text { Kitjaharn, 2002, } \\
\text { Apiratikul et al., } 2004\end{array}$ \\
\hline $\mathrm{Cr}^{+6}$ & Sphaeroplea & $\begin{array}{l}\text { Aeromonas caviae, } \\
\text { Pseudomonas sp. }\end{array}$ & $\begin{array}{l}\text { Waste tea, Coconut Shell } \\
\text { and coconut Husk }\end{array}$ & $\begin{array}{l}\text { Popuri et al., 2007, } \\
\text { Loukidou et al.,2004, } \\
\text { Ziagova et al., 2007, } \\
\text { Olayinka et al., 2007 }\end{array}$ \\
\hline
\end{tabular}

one or a combination of them can be functional in immobilizing metallic species on biosorbents. A number of anionic ligands participate: phosphoryl, carbonyl, sulfhydryl and hydroxyl groups can all be active to various degrees in binding the metals Volesky (1987). Biosorption can be a solution to clean the environment which is contaminated by heavy metals.

Complexation: The metal removal from solution may also take place by complex formation on the cell surface after the interaction between the metal and the active groups. It has been found to be the only mechanism responsible for calcium, magnesium, cadmium, zinc, copper and mercury accumulation by Pseudomonas syringae. Aksu et al., (1992) hypothesized that biosorption of copper by C. vulgaris and Z. ramigera takes place through both adsorption and formation of coordination bonds between metals and amino and carboxyl groups of cell wall polysaccharides. As noted above complex formation of metal ions with organic molecules involves ligand centres in the organic species i.e. the presence of an atom or atoms having lone pairelectrons to donate. Complexation may be electrostatic or covalent and the simplest case is complexation by a mono-dentate ligand such as RNH2. Micro-organisms may also produce organic acids (e.g., citric, oxalic, gluonic, fumaric, lactic and malic acids), which may chelate toxic metals resulting in the formation of metallo-organic molecules (Ahalya et al., 2003).

Chelation: It has been defined as the firm binding of a metal ion with an organic molecule (ligand) to form a ring structure. Organic molecules containing more than one functional group with donor electron pairs can simultaneously donate these to a metal atom. This can result in the formation of a ring structure involving the metal atom. The resulting ring structure protects the mineral from entering into unwanted chemical reactions. In general, since a chelating agent may bond to a metal ion in more than one place simultaneously, cheated compounds are more stable than complexes involving monodentate ligands. Stability tends to increase with the number of chelating sites available on the ligand. Thus chelation of metals by donor ligands of biopolymers leads to the formation of stable species. Examples include the carbonate $\left(\mathrm{CO}_{3}{ }^{2-}\right)$ and oxalate $\left(\mathrm{C}_{2} \mathrm{O}_{4}{ }^{2-}\right)$ ions (The Chemical Engineers' Resource Page, 2008):

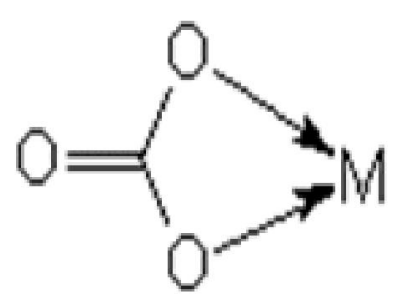

Carbonato complex

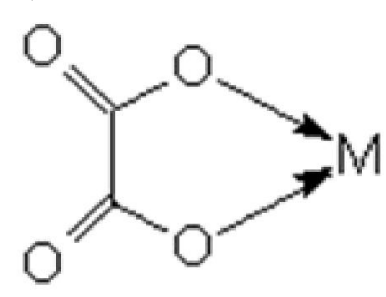

Oxalato complex
Coordination: A coordination complex is any combination of cations with molecules or anions containing free pairs of electrons. In general, biosorption of toxic metals and 
radionuclides is based on non-enzymatic processes such as adsorption. Adsorption is due to the non-specific binding of ionic species to polysaccharides and proteins on the cell surface or outside the cell (Tsezos and Volesky, 1981 and Mullen et al., 1992). Bacterial cell walls and envelopes, and the walls of fungi, yeasts and algae, are efficient metal biosorbents that bind charged groups. The cell walls of gram-positive bacteria bind larger quantities of toxic metals and radionuclides than the envelopes of gram-negative bacteria.

Metal atoms have preferences for specific donor atoms ("hard/hard" / "soft/soft") and the stereochemical arrangements that play an important role in the binding with the available ligands on the microbial cell. Limited information of surface complexation models, based on the theory of surface co-ordination chemistry, is available to describe metal biosorption; however the preferences of the metal species should be considered to explain observed metal biosorption capacities and to elucidate biosorption mechanisms (Tsezos et al., 1995 and Remoudaki et al., 1999).

I on Exchange: It is a process very similar to biosorption whereby the latter is known to actually function predominantly on the basis of ion exchange. Metal ions from dilute solutions are exchanged with ions held by electrostatic forces on the exchange resin. Ion exchange is a reversible chemical reaction wherein an ion in a solution is exchanged for a similarly charged ion attached to an immobile solid particle. According to Muraleedharan and Venkobachr (1990) ion exchange reactions are stoichiometric and reversible, and as such they are similar to other solution-phase reactions. For example, in the reaction

$$
\mathrm{NiSO}_{4}+\mathrm{Ca}(\mathrm{OH})_{2} \rightarrow \mathrm{Ni}(\mathrm{OH})_{2}+\mathrm{CaSO}_{4}
$$

The nickel ions of the nickel sulfate $\left(\mathrm{NiSO}_{4}\right)$ are exchanged for the calcium ions of the calcium hydroxide $\mathrm{Ca}(\mathrm{OH})_{2}$ molecule (The Chemical Engineers' Resource Page, 2008). Precipitation: Precipitation may be either dependent on the cellular metabolism or independent of it. In the former case, the metal removal from solution is often associated with active defense system of the microorganisms (Ahalya et al., 2003). By the addition of appropriate chemicals, followed by conventional solid-liquid removal that could be by sedimentation, flotation, filtration, in extreme cases even by more expensive centrifugation. Precipitation of metals is achieved by the addition of coagulants such as alum, lime, iron salts and other organic polymers. The large amount of sludge containing toxic compounds produced during the process is the main disadvantage.

\section{Conclusion}

The presence of heavy metals in the environment is of major concern because of their toxicity, bio-accumulating tendency, threat to human life and the environment. However the natural biogeochemical cycles are disrupted due to various human activities like ore mining and industrial processes causing increased deposition of heavy metals in terrestrial and aquatic environment.

Biosorption of heavy metals by microbial cells has been recognized as a potential alternative to existing conventional technologies for waste streams and natural waters. Some biosorbents such as algae, bacteria, fungi and agricultural by-products are examples of biomass tested for metal biosorption with very hopeful results and very effective in accumulating heavy metals. Therefore, biosorption of heavy metals by microbial biomass is being strongly recommended as a powerful technique for the removal of heavy metals from polluted effluents. This will be beneficial not only to the industries, but also to the living organisms and the surrounding environment. The obvious advantages of biosorption process as compared to conventional techniques are their low cost involved when agricultural products and byproducts are used. Agricultural products and by-products are an abundant waste materials that may be procured free of cost. The agricultural waste could be used as potential adsorbent for the removal of metals from waste water. Thus, the removal of metals from aqueous solutions using biosorption process can be a solution to clean the environment. This advance technology is not only cheaper and more effective, but also quick and easy to operate.

\section{ACK NOW LEDGEMENTS}

The University Grants Commission New Delhi, India is acknowledged for providing the financial support in the form of UGC research fellowship (F.7-70/2007 BSR) to Chakresh Pathak.

\section{REFERENCES}

Adesola Babarinde, N. A., Oyebamiji.Babalola, J. and Adebowale Sanni, R. (2006). Biosorption of lead ions from aqueous solution by maize leaf. International J ournal of Physical Sciences, 1(1): 023-026.

Ahalya, N., Ramachandra, T.V. and Kanamadi, R.D. (2003). Biosorption of heavy metals. Res. J. Chem. E nviron., 7: 7178.

Al-fawwaz, A.T. and Wan Maznah, W.O. (2008). Biosorption of Copper Using Live and Dead Green Microalgae Isolated from Penang Rivers, Malaysia. International Conference on Environmental Research and Technology (ICERT 2008).

Aksu, Z., Sag, Y. and Kutsal, T. (1992). The biosorption of $\mathrm{Cu}$ (II) by C. vulgaris and Z. ramigera. Environ. Technol., 13: 579-586.

Akthar, N., Sastry, S. and Mohan, M. (1995). Biosorption of Silver Ions by Processed A sper gillus niger Biomass. Biotech. Letters, 17: 551-556.

Antunes, W. M., Aderval, S. Luna, Cristiane A. Henriques and Antonio Carlos A. da Costa (2003). An evaluation of copper 
biosorption by a brown seaweed under optimized Conditions. Electronic J ournal of Biotechnology, 6 (3):174184.

Apiratikul, R., Marhaba, T.F., Wattanachira, S. and Pavasant, P. (2004). Biosorption of binary mixtures of heavy metals by green macro alga, Caulerpa lentillifera. Songklanakarin J. Sci. Technol., 26(Suppl. 1) : 199-207

Ashkenazy, R., Gottlieb, L. and Yannai. S. (1997). Characterization of acetone washed yeast biomass functional groups involved in lead biosorption. Biotechnology and Bioengineering, 55: 1-10.

Agency for toxic substances and disease registry (1999a). Toxicological profile for Lead. US Department of Health and Human Services, Public Health Service. 205-93-0606.

Agency for toxic substances and disease registry (1999b). Toxicological profile for Cadmium. US Department of Health and Human Services, Public Health Service. 205-93-0606.

ATSDR. (1994). Toxicological profile for Zinc. US Department of Health and Human Services, Public Health Service. 20588-0608.

Ayla, O., Dursun, O. and H. Ibrahim Ekiz (2004). The Equilibrium and Kinetic Modelling of the Biosorption of Copper (II) Ions on Cladophora crispate. Adsorption, 10: 317-326.

Baker, D.E, Amacher, M.C. and Leach, R.M. (1979). Sewage sludge as a source of cadmium in soil-plant animal systems. Environ. Heal th Perspect., 28:45-49.

Bailey, S. E., Olin, T. J., Bricka, R. M. and Adrian, D. A. (1999). A review of potentially low-cost sorbents for heavy metals, Wat. Res., 33 (11) : 2469-2479.

Beolchini, F., Pagnanelli, F., Toro, L. and Vegliò, F. (2006). Ionic strength effect on copper biosorption by Sphaerotilus natans: equilibrium study and dynamic modelling in membrane reactor. Water Res., 40:144-152.

Beveridge, T.J. (1989). The role of cellular design in bacterial metal accumulation and mineralization. Annu Rev M icrobiol., 43:147-171.

Brown, P. A., Gill, S. A. and Allen, S. J. (2000). Metal removal from wastewater using Peat. Water Res., 34 (16): 3907 3916 (10 Pages), DOI: 10.1016/S0043-1354(00)00152-4.

Cesar, R.T. and Marco, A.Z.A. (2004). Biosorption of heavy metals using rice milling by-products: characterisation and application for removal of metals from aqueous effluents. Chemosphere, 54:987-995.

Choi, S.B. and Yun, Y.S.(2004). Lead biosorption by waste biomass of Corynebacterium glutamicum generated from lysine fermentation process. Biotechnol L ett ., 26:331-6.

Churchill, S.A., Walters, J.V. and Churchill, P.F. (1995). Sorption of heavy metals by prepared bacterial cell surfaces. J. Environ. Eng., 121: 706-711.

Chandra, K., Kamala, C.T., Chary, N.S., and Anjaneyulu, Y. (2003). Removal of heavy metals using a plant biomass with reference to environmental control. International J ournal of Mineral Processing, 68: 37-45.

Chen, GQ., Zeng, GM. and Tang, L. (2008). Cadmium removal from simulated wastewater to biomass byproduct of Lentinus edodes. Bioresour Technol., 99:7034-7040.

Crini, G. (2006). Non-conventional low-cost adsorbents for dye removal: A review. Bioresource Technology, 97: 10611085 .
Deng, L.P., Su, Y.Y., Su, H., Wang, X.T. and Zhu, X.B. (2007). Sorption and desorption of lead (II) from wastewater by green algae Cladophora fascicularis. J Hazard Mater, 143:220-225.

Duruibe, J. O., Ogwuegbu, M. O. C. and Egwurugwu, J. N. (2007). Heavy metal pollution and human biotoxic effects. International J ournal of Physical Sciences, 2 (5):112-118.

EPA. (1994). Integrated Risk Information System-Cadmium. US Environmental Protection Agency; Report nr 7440-439.

Figueira, M. M., Volesky, B. and Mathieu, H. J. (1999). Instrumental Analysis Study of Iron Species Biosorption by Sargassum Biomass. Environ. Sci. Technol., 33 :1840.

Fourest, E., Canal, C. and Roux, J. C. (1992). Improvement of heavy metal biosorption by mycelial dead biomasses (Rhizopus arrhizus, Muchor miehei, and Pencillium chrysogenum): $\mathrm{pH}$ control and cationic activation. FEMS M icrobiology Reviews, 14: 325-332.

Fourest, E. and Volesky, B. (1997). Alginate properties and heavy metal biosorption by marine algae. Appl. Biochem. Biotechnol., 67:33-44.

Francesca, P., Sara, M. and Francesco, V. (2003). Heavy metal removal by olive pomace: biosorbent characterisation and equilibrium modeling. C hem Eng Sci., 58:4709-4717.

Gardea-Torrsday, J. L., Tiemann, K. J., Peralta-Videa, J. R., Paeron, J. G., Delgado, M. (2004). J . M icrochem., 76 : 65.

Garcia, W.J., Blessin, C.W., Sandford, H.W. and Inglett, G.E. (1979). Translocation and accumulation of seven heavy metals in tissues of corn plants grown on sludge-treated strip-mined soil. J. Agric. Food C hem., 27(5): 1088-94.

Green-Ruiz C.(2006). Mercury (II) removal from aqueous solutions by nonviable Bacillus sp. from a tropical estuary. Biores Technol., 97:1907-1911.

Guangyu, Y. and Thiruvenkatachari, V. (2003). Heavy metal removal from aqueous solution by fungus Mucor rouxil. Water Res., 37:4486-4496.

Guibal E, Roulph C. and Cloirec PL (1995). Infrared spectroscopic study of uranyl biosorption by fungal biomass and materials of biological origin, E nviron. Sci. Technol. 29: 2496-2502

Gupta, G. S., Shukla, S. P., Parsad, G. and Singh, V. N. (1992). China clay as an adsorbent for dye house wastewater. Environmental Technology, 13: 925-936.

Gallardo-Lara, F., Azcon, M., Quesada, J.L. and Polo, A. (1999). Phytoavailability and extractability of copper and zinc in calcareous soil amended with composted urban wastes. J. Environ. Sci. Health B, 34(6): 1049-64.

Hameed, M. S.A. (2006). Continuous removal and recovery of lead by alginate beads, free and alginate-immobilized Chlorella vulgaris. African J ournal of Biotechnology. 5 (19):1819-1823.

Hanif, M. A., Nadeem, R., Bhatti, H. N., Ahmad, N. R. and Ansari, T. M. (2007). Ni (II) biosorption by Cassia fistula (Golden Shower) biomass. J ournal of H azardous M aterials B, 139:345-355.

Horsfall, M. J., Abia, A. A. and Spiff, A.I. (2003). Removal of $\mathrm{Cu}$ (II) and $\mathrm{Zn}$ (II) ions from wastewater by cassava (M anihot esculenta Cranz) waste biomass.African J ournal of Biotechnology, 2 (10):360-364.

Hosea, M., Greene, B., McPherson, R., Henzl, M., Alexander, 
M.D. and Darnall, D.W. (1986). Accumulation of elemental gold on the alga Chlorella vulgaris. Inorg Chim Acta.,123:161-165.

Hu, M.Z.C., Norman, J.M., Faison, N.B. and Reeves, M. (1996) Biosorption of uranium by Pseudomonas aeruginosa strain CSU: characterization and comparison studies. Biotechnol Bioeng, 51:237-247.

Indian standards for drinking water-Specification (BIS 105001991)

Incharoensakdi A. and Kitjaharn P. (2002). Zinc biosorption from aqueous solution by a halotolerant cyanobacterium Aphanothece halophytica. C urr M icrobiol., 45:261-264.

Jain, S.K., Vasudevan, P., and Jha, N. K. (1989). Removal of some heavy metals from polluted water by aquatic plants: studies on duckweed and water velvet, Biol. Wastes, 28 : 115-126.

Javaid, A. and Bajwa, R. (2008). Biosorption of electroplating heavy metals by some basidiomycetes. M ycopath, $6(1 \& 2)$ : $1-6$.

Jing, Y., He, Z. and Yang, X. (2007). Role of soil rhizobacteria in phytoremediation of heavy metal contaminated soils. J Zhejiang Univ Sci B. 8:192-207.

Jooste, S. (2000). A model to estimate the total ecological risk in the management of water resources subject to multiple stressors. Water SA., 26(2): 159-166.

Kapoor A. and Viraraghavan T.(1997). Heavy metal biosorption sites in Aspergillus niger. Biores Technol., 61:221-227.

Kaewchai, S. and Prasertsan, P. (2002).Biosorption of heavy metal by thermotolerant polymer-producing bacterial cells and the bioflocculant. Songklanakarin J . Sci. Technol., 24(3): 421-430.

Kuyucak, N. and Volesky, B. (1989). Accumulation of cobalt by marine alga. Biotechnology and Bioengineering, 33 (7):809-814.

Kobya, M., Demirbas, E., Senturk, E. and Ince, M. (2005). Adsorption of heavy metal ions from aqueous solutions by activated carbon prepared from apricot stone. Bioresour. Technol., 96(13): 1518-1521.

Kosla, T. (1986). Studies of the levels of copper and zinc in the soil, grass and blood serum and hair of bulls from the areas irrigated with waste water from the Ner River. Pol. Arch. Water, 25(1):145-154.

Kumar, U. and Bandyopadhyay, M. (2006). Sorption of cadmium from aqueous solutions using pretreated rice husk. Bioresource Technology, 97: 104-109.

Kratochvil, D. and Volesky, B. (1998). Advances in the biosorption of heavy metals. Trends Biotechnol., 16:291300.

Karvelas, M., Katsoyiannis, A. and Samara, C. (2003). Occurance and fate of heavy metals in the wastewater treatment process. Chemosphere, 53: 1201-1210.

Kratochvil, D., Pimentel, P. and Volesky, B. (1998). Removal of trivalent chromium by seaweed biosorbent. Environment Science and Technology, 32:2693-2698.

Lau, P. S., Lee, H. Y., Tsang, C. C. K., Tam, N. F. Y. and Wong, Y. S. (1999). Effect of Metal Interference, $\mathrm{pH}$ and Temperature on $\mathrm{Cu}$ and $\mathrm{Ni}$ Biosorption by $\mathrm{Chlorella}$ Vulgaris and Chlorella M iniata. Environmental Technology, 20 (9): $953-961$.
Liu, Ting, Huidong Li, Zhao Li, Xiao Xiao, Lingli Chen and Le Deng (2007).Removal of hexavalent chromium by fungal biomass of Mucor racemosus: influencing factors and removal mechanism. World J M icrobiol Biotechnol, 23:16851693.

Liao, J., Ning Liu, Yuanyou Yang, Shunzhong Luo, Qiang Luo, Zhu An, Yanmin Duan, Mantian Liu, Pengji Zhao(2008). Preliminary investigation on biosorption mechanism of ${ }^{241} \mathrm{Am}$ by Rhizopus arrhizus. Journal of Radioanalytical and Nuclear Chemistry, 277(2): 329-336.

Lone, M. I., He, Z., Stoffella, P. J and Yang, X. (2008). Phytoremediation of heavy metal polluted soils and water: progress and perspectives. J . Zhejiang U niv Sci B, 9: 210220.

Leung, W.C., Wong, M.F., Chua, H., Lo, W., Yu, P.H.F. and Leung, C.K. (2000). Removal and recovery of heavy metals by bacteria isolated from activated sludge treating industrial effluents and municipal wastewaters. Water Science and Technology, 41(12): 233-240.

Loukidou, M.X., Karapantsios, T.D., Zouboulis, A.I., Matis K.A. (2004). Diffusion kinetic study of cadmium (II) biosorption by Aeromonas caviae. J Chem Technol Biotechnol.,79:711-9.

Lo, W., Chua, H., Lam, K.H. and Bi, S.P. (1999). A comparative investigation on the biosorption of lead by filamentous fungal biomass, Chemosphere, 39(15): 2723-2736.

Mann H (1990). Biosorption of heavy metals by bacterial biomass. In: Volesky B (ed) Biosorption of heavy metals CRC Press, Boca Raton, FL, pp 93-137

Manju, G. N. and Anirudhan, T. S. (1997). Use of coconut fiber Pith-based Pseudo-activated carbon for Chromium (VI) removal. Indian J . E nviron. H ealth, 39 (4):289-298.

Moustafa, M. and Idris, G. (2003). Biological removal of heavy metals from wastewater. Alexandria Engineering J ournal, 42 (6): 767-771.

Muraleedharan, T.R and Venkobachr, C. (1990). Mechanisms of biosorption of $\mathrm{Cu}(\mathrm{II})$ by $\mathrm{G}$ anoder ma lucidum. B iotechnol. Bioeng., 35: 320-325.

Mullen, M.D., Wolf, D.C., Beveridge, T.J. and Bailey, G.W. (1992). Sorption of heavy metals by soil fungi Aspergillus niger and Mucor Rouxii. In Soil Biol. Biochem. 24, 129-135.

Metcalf and Eddy, Inc.(1991). Waste Water Engineering. Treatment, Disposal and Reuse (3rd ed.), McGraw- Hill, New York. p. 265.

Mufti, S.A., Woods, C.A. and Hasan, S.A. (1997). Biodiversity of Pakistan. Islamabad: Pakistan Museum Natural History.

Omar, H.H. (2002). Bioremoval of Zinc ions by Scenedesmus obliques and Scenedesmus quadricauda and its effect on growth and metabolism. Int. Biodeterior. Bioderad., 50:95100.

Omar, H.H. (2008). Biosorption of copper, nickel and manganese using non-living biomass of marine alga, U Iva lactuca. Pakistan J ournal of Biological Scineces, 11(7):964 973.

Olga, M.M.F., Ramiro, J.E.M. and Cristina, M. (2008). Removal of $\mathrm{Cd}$ (II), $\mathrm{Zn}$ (II) and $\mathrm{Pb}$ (II) from aqueous solutions by brown marine macro algae: kinetic modelling. J . H azard. Mater., 153:493-501.

Olayinka, K. O., Alo, B. I. and Adu, T. (2007). Sorption of heavy metals from electroplating effluents by low cost 
absorbent II: use of waste tea, coconut shell and coconut husk. J ournal of A ppplied sciences, 7(16):2307-2313.

Öztürk, A., Artan, T. and Ayar, A. (2004). Biosorption of nickel (II) and copper (II) ions from aqueous solution by Streptomyces coelicolor A3(2). Colloids Surf B Biointerfaces, 34:105-111.

Öztürk, A. (2007). Removal of nickel from aqueous solution by the bacterium Bacillus thuringiensis. J Hazard Mater, 147:518-523.

Preetha, R. and Kumar, T. S. (2008). Rhizosphere treatment technology for community waste water treatment, EJ EAFC he, 7 (13):2661-2666.

Pino, G. H., de Mesquita, L. M. S., Torem, M. L. and Pinto, G. A. S. (2006). Biosorption of heavy metals by powder of green coconut shell. Separation Science and Technology, 41 (14): 3141-3153.

Popuri, S. R., Kalyani, S., Kachireddy, S. R. and Krishnaiah, A. (2007).Biosorption of hexavalent Chromium from aqouus solution by using prawn pond algae (Sphaeroplea).Indian J ournal of Chemistry 46 (A) :284-289.

Park, D., Lim, S.R., Yun, Y.S., Park, J.M. (2008). Development of a new $\mathrm{Cr}$ (VI)-biosorbent from agricultural biowaste. Bioresour. Technol., 99: 8810-8818.

Patricia, M., Andrea, S. and Alicia, F. C. (2006) Simultaneous heavy metal removal mechanism by dead macrophytes. Chemospher, 62:247-254.

Peles, J., Brewer, S. and Barrett, G. (1998). Heavy metal accumulation by old-field plant species during recovery of sludge-treated ecosystems. The Am. Mid. Naturalist, 140 (2): 245-251.

Radway, J. C., Wilde, E.W., Whitakar, M.J. and Wessman, J.C. (2001). Screening of algal strains for metal removal capabilities. J. Applied Phycol., 13:451-455.

Rajendran, P., AshokKumar, B., Muthukrishnan, J. and Gunasekaran, P. (2002). Toxicity assessment of nickel using aspergillus niger and its removal from an industrial effluent. Applied Biochemistry and Biotechnology, 201:102-103.

Ramakrishna, K. R. and Viraraghavan, T. (1997). Dye removal using low cost adsorbents. Water Science and Technology, 36:189-196.

Rezaee, A., Ramavandi, B. and Ganati, F. (2006). Equilibrium and spectroscopic studies on biosorption of mercury by algae biomass. Pakistan J ournal of Biological Sciences, 9 (4): 777-782.

Raji, C. and Anirudhan, T.S. (1997). Chromium (VI) adsorption by sawdust carbon: Kinetics and equilibrium. Indian J . Chem. Technol, 4:228-239.

Remoudaki, E., Tsezos, M., Hatzikioeyian, A. and Karakoussis, V. (1999). Mechanism of palladium biosorption by microbial biomass. The effects of metal ionic speciation and solution co-ions. in International Biohydrometallurgy Symposium IBS 99: Biohydrometallurgy and the Environment toward the mining of the 21 st Century.: Elsevier.

Romera, E., Gonzalez, F., Ballester, A., Blázquez, M., and Munoz, J. (2006). Biosorbtion with Algae: A statistical review. C ritical Reviews in Biotechnology, 26:223-235.

Schneider, I. A. H., Rubio,J., and R. W. Smith (2001). Biosorption of Metals onto plant biomass : Exchange, Adsorption and Surface precipitation?. Int. J . M iner. Process. 62: $111-120$
Sarret, G., Manceau, A., Spadini, L., Roux, J. C., Hazemann, J. L., Soldo, Y. Eybent-Berard, L. and Menthonnex, J. J. (1999). Structural determination of $\mathrm{Pb}$ binding sites in Penicillium chrysogenum cell walls by EXAFS spectroscopy and solution chemistry, J. Synchrotron Radiation , 6: 414416.

Selatnia, A., Madani, A., Bakhti, M. Z., Kertous, L., Mansouri, Y., and Yous, R. (2004). Biosorption of $\mathrm{Ni}^{2+}$ from aqueous solution by a $\mathrm{NaOH}$-treated bacterial dead Streptomyces rimosus biomass. M inerals Engineering, 17: 903-911.

Schiewer,S. (1999). Modelling complexation and electrostatic attraction in heavy metal biosorption by Sargassum biomass. I. Appl. Phycology, 11:79.

Strandberg, G.W., Shumate, S.E. and Parrot, J.R. (1981). Microbial cells as biosorbents of heavy metals: Accumulation of uranium by Sacchar omyces cer evisiae and Pseudomonas aeruginosa. Appl Environ M icrobiol., 41:237-245.

Suresh, B. and Ravishankar, G. A. (2004). PhytoremediationA Novel and Promising Approach for Environmental Cleanup. Critical Reviews in Biotechnology, 24: 97-124.

Sheng, P.X., Ting, Y.P. and Paul, C. J. (2004). Sorption of cadmium, copper, cadmium, zinc, and nickel by marine algal biomass: characterization of biosorptive capacity andinvestigation of mechanisms. J Colloid Interf Sci, 275:131-141.

The Chemical Engineers' Resource Page (2008). www.cheresources.com, 1442 Goswick Ridge Road, Midlothian, VA 23114.

Tipping, E. (2002). Cation binding by humic substances, 1st Edition; Cambridge Environmental Chemistry Series: Cambridge, UK.

Tsezos, M., E. Remoundaki, and V. Angelatou (1995). A systematic study on equilibrium and kinetics of biosorptive accumulation. The Case of $\mathrm{Ag}$ and $\mathrm{Ni}$. Int. Biodeter. Biodegrad., 35: 129-153.

Tsezos, M. and Volesky, B. (1982). The mechanism of uranium biosorption. Biotechnol. Bioeng., 24: 385-401.

Tsezos M. and Volesky B (1981) Biosorption of Uranium and thorium. Biotechnol. and Bioeng. 23: 583 - 604.

Tomko J., Baèkor M., Štofko M. (2006). Biosorption of heavy metals by dry fungi biomass. Acta Metallurgica Slovaca, 12:447-451.

Todd, A.C., Wetmur, J.G., Moline, J.M., Godbold, J.H., Levin, S.M. and Landrigan, P.J. (1996). Unraveling the chronic toxicity of lead: an essential priority for environmental health. Environ. Health Perspect. 104 Suppl. 1:141-6.

Unz, R.F. and Shuttleworth, K.L. (1996). Microbial mobilization and immobilization of heavy metals. Curr. Opin. Biotechnol., 7(3): 307-310.

Uslu G. and Tanyol, M. (2006). Equilibrium and thermodynamic parameters of single and binary mixture biosorption of lead(II) and copper(II) ions onto Pseudomonas putida: effect of temperature.J H azard M ater, 135:87-93.

Veglio, F. and Beolchini, F. (1997). Removal of metals by biosorption: a review, Hydrometallurgy, 44 (3): 301-316.

Venkata Subbaiah, M., Kalyani, S. Sankara Reddy, G., Veera M. Boddu and A. Krishnaiah (2008). Biosorption of Cr (VI) from aqueous solutions using Trametes ver sicolor polyporus fungi. E-J ournal of Chemistry, 5 (3): 499-510. 
Vitor, J.P.V., Cidalia, M.S.B. and Rui, A.R.B. (2007). Chromium and zinc uptake by algae Gelidium and agar extraction algal waste: Kinetics and equilibrium. J Hazard M ater, 149:643649.

Vieira, D. M., Antonio C. A. da Costa, Cristiane A. H., Vicelma L. C. and Francisca Pessôa de França (2007). Biosorption of lead by the brown seaweed Sargassum filipendula - batch and continuous pilot studies. Electronic Journal of Biotechnology, 10 (3):368-375.

Vijayaraghavan, K. and Yeoung-Sang, Y. (2008). Bacterial biosorbents and biosorption. Biotechnology Advances, 26:266-291.

Volesky, B. (1987). Biosorbents for metal recovery. Trends Biotechnol., 5: 96-101.

Volesky, B. and May-Phillips, H.A. (1995). Biosorption of heavy metals by Saccharomyces cer evisiae. Appl. Microbiol. Biotechnol., 42, 797.

Volesky, B. (1990). Biosorption of Heavy Metals. CRC Press, Boca Ratton, USA.

Volesky, B. and Schiewer, S. (1999). Biosorption of metals. In: Encyclopedia of Bioprocess Technology (Flickinger M, Drew SW, eds.). New York: Wiley. 433-435.

Volesky, B., (2001). Detoxification of metal-bearing effluents: biosorption for the next century, Hydrometallurgy, 59 (23): 203-216.

Won, S.W., Choi, S. B. and Yun, Y. S. (2005). Interaction between protonated waste biomass of $\mathrm{C}$ orynebacterium glutamicum and anionic dye Reactive Red 4. Colloids and Surfaces A: Physicochemical and Engineering Aspects, 262: 175-180.

Warhusta, M., Mcconna, Chie, G.L. and Ulmuslardsj, T. (1997). Characterization and applications of activated carbon producted from M oringa oleifera seed husk by single-step steam pyrolysis. Water Res., 31:759-766.

Williams, P.T. and Nugranad, N. (2000). Comparison of products from the pyrolysis and catalytic pyrolysis of rice husks. Energy, 25: 493-513.

Wase, J. and C. Forster (1997). Biosorbents for M etal Ions. Taylor and Francis Ltd.

Wuyep, P. A., Chuma, A. G., Awodi, S. and Nok, A. J. (2007). Biosorption of $\mathrm{Cr}, \mathrm{Mn}, \mathrm{Fe}, \mathrm{Ni}, \mathrm{Cu}$ and $\mathrm{Pb}$ metals from petroleum refinery effluent by calcium alginate immobilized mycelia of Polyporus squamosus. Scientific Research and Essay, 2 (7): 217-221.

Yun, Y. S. (2004). Characterization of functional groups of protonated Sargassum polycystum biomass capable of binding protons and metal ions. Journal Microbiology Biotechnology, 14: 29-34.

Yun, Y. S., Park, D., Park, J. M. and Volesky, B. (2001). Biosorption of trivalent chromium on the brown seaweed biomass. Environmental Science and Technology, 35: 43534358.

Yu, Q. and Kaewsarn, P. (1999). A model for $\mathrm{pH}$ dependent equilibrium of heavy metal biosorption. Korean J. Chem. Eng., 16(6): 753-757.

Yilmaz, E.I. and Ensari, N.Y. (2005). Cadmium biosorption by Bacillus circulans strain EB1. World J M icrobiol Biotechnol., 21:777-779.

Ziagova, M., Dimitriadis, G., Aslanidou, D., Papaioannou, X., Tzannetaki, E.L., Liakopoulou-Kyriakides, M.(2007). Comparative study of $\mathrm{Cd}$ (II) and $\mathrm{Cr}(\mathrm{VI})$ biosorption on Staphylococcus xylosus and Pseudomonas sp. in single and binary mixtures. Biores. Technol., 98:2859-2865. 